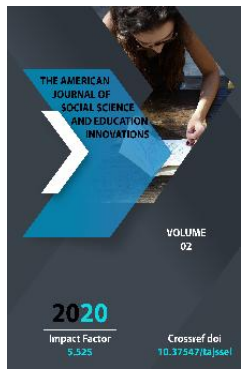

Journal Website: http://usajournalshub.c om/index,php/tajssei

Copyright: Original content from this work may be used under the terms of the creative commons attributes 4.0 licence.

\section{The Issue Of Cooperation Of The Mahalla Institution With Governmental And Non-Governmental Organizations On Employment Of Youth (On The Example Mahallas In Tashkent)}

Bobojonov I. U. 07.00.01 Of Tashkent State Pedagogical University, A Base Doctoral Student On The Specialty History Of Uzbekistan, Tashkent, Uzbekistan

\title{
ABSTRACT
}

This article analyzes the reforms implementing in Uzbekistan in the field of employment of the people, particularly youth, as well as the issue of cooperation of the mahalla institution with governmental and non-governmental organizations on the example of mahallas in Tashkent. The article is based on accurate statistics in analyzing the reforms implemented during independence. It also discusses the current problems related to unemployment in the world and Uzbekistan.

\section{KEYWORDS}

Mahalla, law, decision, system, chairperson of mahalla, commission, reform, self-government body, authority.

\section{INTRODUCTION}

It is known that the issue of employment of the people in the countries of the world is equally the matter of great concern to the heads of state. In particular, unexpectedly, the spread of a Coronavirus infection in Wuhan in China, and spreading to other countries at a rapid pace have made the problem of unemployment even more serious in front of the leaders of the countries in the world. Many restrictions in actions due to the pandemic of Covid - 19 also affected the labor migration. This situation, in turn, has led to a more serious global problem of unemployment. According to the data provided by the International Labor Organization, in the case of July 2020, 190.3 million people worldwide are suffering from the problem of unemployment. According to experts, this figure will reach 199.8 million in 2023 [1]. At the same time, the number of 
working poor in the world is increasing. In addition, according to the additional information provided by the organization, the workers who receive a low salary for their labor are also in the majority. It is worth noting that the problem of unemployment, which is torturing the whole world, is also identified in Uzbekistan as a priority direction of state policy. In particular, during the years of independence attention has been paid to the employment of the people, financial support for the needy, and to create of the conditions for them to receive income in an appropriate order. However, the efforts implemented over the past years has not been enough to sort out the problem.

\section{METHODOLOGY}

The study was conducted using objectivity, analysis, synthesis, comparative analysis, generalization, historical analysis, chronological methods.

\section{RESULTS}

At present, the lowest unemployment rate in Uzbekistan corresponds to Tashkent, and this rate constituent $7.8 \%$ compared to the economically active people. The highest rates are in Samarkand and Surkhandarya regions [2]. The number of permanent inhabitants in Tashkent is about 3 million people. Of these, 1.1 million are employed people, about 99000 are unemployed, and more than 90000 thousand are labor migrants. Also, almost 39 thousand people are young people entering the labor market for the first time this year. The potential unemployment rate in the city is 20 percent [3]. As Tashkent, being the capital city unemployment is rising at the expense of job seekers from the regions. 
Statistical data on economically active, employed, and unemployed people of Tashkent for 20002017 [4].

\begin{tabular}{|c|c|c|c|c|c|c|}
\hline \multirow[b]{2}{*}{ Periods } & \multirow{2}{*}{$\begin{array}{c}\text { Financially } \\
\text { active } \\
\text { people, } \\
\text { (total, by } \\
\text { thousand } \\
\text { people) }\end{array}$} & \multicolumn{2}{|c|}{ From them } & \multirow[b]{2}{*}{$\begin{array}{c}\text { Level of } \\
\text { financially } \\
\text { active } \\
\text { people* } \\
(\%)\end{array}$} & \multirow[b]{2}{*}{$\begin{array}{c}\text { Level of } \\
\text { employed } \\
\text { people*** } \\
(\%)\end{array}$} & \multirow[b]{2}{*}{$\begin{array}{c}\text { Level of } \\
\text { unemployment } \\
(\%)\end{array}$} \\
\hline & & $\begin{array}{c}\text { Employed } \\
\text { (total, by a } \\
\text { thousand } \\
\text { people) }\end{array}$ & $\begin{array}{c}\text { Unemployed } \\
\text { (total, by a } \\
\text { thousand } \\
\text { people) }\end{array}$ & & & \\
\hline 2000 & 1007,9 & 1005,2 & 2,7 & 78,9 & 78,7 & 0,3 \\
\hline 2001 & 1025,8 & 1022,8 & 3 & 79,5 & 79,2 & 0,3 \\
\hline 2002 & 1047,7 & 1045,1 & 2,6 & 80,3 & 80,1 & 0,2 \\
\hline 2003 & 1076,8 & 1074,2 & 2,6 & 81,7 & 81,5 & 0,2 \\
\hline 2004 & 1109,7 & 1107,7 & 2 & 83,6 & 83,4 & 0,2 \\
\hline 2005 & 1126,3 & 1124,3 & 2 & 84,2 & 84,1 & 0,2 \\
\hline 2006 & 1129,2 & 1127,2 & 2 & 83,7 & 83,5 & 0,2 \\
\hline 2007 & 1171 & 1132,4 & 38,6 & 85,9 & 83 & 3,3 \\
\hline 2008 & 1179,4 & 1140,8 & 38,6 & 85,6 & 82,8 & 3,3 \\
\hline 2009 & 1187,1 & 1146,5 & 40,6 & 85,8 & 83 & 3,4 \\
\hline 2010 & 1193,6 & 1153,8 & 39,8 & 84,5 & 81,6 & 3,3 \\
\hline 2011 & 1197,3 & 1156,7 & 40,6 & 83,6 & 80,7 & 3,4 \\
\hline 2012 & 1201,4 & 1162,2 & 39,2 & 83,4 & 80,7 & 3,3 \\
\hline 2013 & 1206,6 & 1165,3 & 41,3 & 83,5 & 80,7 & 3,4 \\
\hline 2014 & 1210,1 & 1166,5 & 43,6 & 84 & 80,9 & 3,6 \\
\hline 2015 & 1214,6 & 1168,1 & 46,5 & 84,3 & 81,1 & 3,8 \\
\hline 2016 & 1213,6 & 1169,7 & 43,9 & 84,1 & 81 & 3,6 \\
\hline 2017 & 1226,8 & 1171,4 & 55,4 & 84,6 & 80,8 & 4,5 \\
\hline
\end{tabular}

*The ratio of financially active people to the number of people on the age able to work

** The ratio of employed people to the number of people on the age able to work

When analyzing the employment and unemployment level of the people in Tashkent between 2000-2017 years based on the data of the State Committee of the Republic of Uzbekistan on Statistics, we can see that, along with the increase in the number of financially active people, the unemployment rate also increased. In the 2000 year, the unemployment rate compared to the financially active people was $0.3 \%$, by 2017 this figure reached $4.5 \%$. Growing of the issues of unemployment year by year can be explained by the following reasons:

Firstly, influxes of unemployed people from other parts of the country to Tashkent in search of work led to an increase in the number of unemployed people in the capital.

Secondly, increasing the number of youth on the age able to work contributed to the increase in the number of unemployed people. Most of them were young people with secondary special education, who graduated 
from vocational colleges. Along with the establishment of vocational colleges, it was faced challenges in creating new jobs for the graduates.

Thirdly, despite opening a wide road to the development of small business and private entrepreneurship, the lack of experience and knowledge of the young people on creating a business plan, Finance, and credit has also led to an increase in the number of unemployed.

In the early years of independence, we can see that the role and powers of government agencies were wide in employing the people, particularly youngsters. The announcement of the "Concept of further deepening democratic reforms and development of civil society in the country" by the President of the Republic of Uzbekistan on November 12, 2010, served to increase the role and powers of public organizations in this area.

It is worth noting that the Republic of Uzbekistan has organized activities in reducing the level of unemployment, namely, in the employment of its population, by giving broad authority not only to the Ministry of employment and labor relations or to local authorities, but also public organizations, in particular to the mahalla institute. Consequently, one of the main functions of the mahalla institute gradually developed during the years of independence is to provide employment and financial support to unemployed youth in the territory of mahalla.

The "Yoshlik" mahalla citizens "gathering in the Almazar district of Tashkent has carried out several activities on the employment of young people. At the initiative of activists of this mahalla, 12 unemployed youth were provided with jobs during 2011-2015. It can also be acknowledged, systematic work has been set up to employ unemployed youth in the mahallas like Axil, Abu Bakr Shoshiy, Orzu, Beruniy. During these years, at the initiative of the mahalla citizens' gathering in Almazar district, 92 young people were provided with the job in cooperation with the district administration, the District Council of the Youth Union. 32 of them were provided with the position in the state organization, 60 of them had a position in the private sector [5].

There are 4,527 young people under the age of 30 in "Kokcha" mahalla citizens' gathering in Shayhantahur district. Those under the age of 17 are 2015 people, 60 of them are students. 128 young people from the mahalla work in state enterprises and organizations. At present, the number of youth who do not work and do not study anywhere is 8,4 young people have gone to a foreign country to work [6]. In 2019, Ikramova Umida (born 1997 year), Toshimova Nodira, and Toshimov Sulton were involved in public work in the mahalla. Currently, under the leadership of the chairperson of the mahalla Z.Z Karimova and a group of activists, practical actions are being taken to provide jobs for unemployed youth in the mahalla. However, it is also necessary to note that in some cases, youth have to deny such proposals because the work offered to unemployed youth is far from the area of the mahalla, the salary is low and does not even exceed the daily expenses. Consequently, it is necessary to develop the establishment of additional vocational training centers in mahalla citizens' gatherings. In general, Kokcha MCG of the capital can be recognized as a model mahalla.

President of the Republic of Uzbekistan Mirziyoyev emphasized the issue of 
employment of young people and noted that in the strategy of actions announced on February 7, 2017, "It is planned to create 46.8 thousand new jobs in the regions with the highest unemployment rates and to provide loans to 10,000 graduates of educational institutions to start their business activities [7]".

Resolution of the Cabinet of Ministers of the Republic of Uzbekistan No. 944 "on approval of the Regulations on the regulation of employment relationships in self-government institutions of citizens", published on 27 November 2017, plays a significant role in the addressing positively existing problems of employment of unemployed people [8].

In accordance with chapter 2, Part 5 of the Regulations on the regulation of employment relationships in self-government institutions of citizens, approved based on this Resolution, the chairman (aksakal) of the citizens' gaziring has the right to conclude employment contracts with unemployed people living in the territory of the mahalla to involve them in community work and the expense paid by the Community Affairs Fund under the Ministry of Employment and Labor Relations of the Republic of Uzbekistan to them [9]. As a result, the aksakal of the mahalla can employ officially the unemployed and low-income people in his territory, and on his recommendation, the unemployed person in the mahalla can get a bank loan and start his business. Indeed, through the ongoing reforms, the role and powers of the mahalla institute gradually expanding, and fulfilling the important task of bridging the gap between the people because of the assumption of many functions performed by local authorities, and becoming the most important link in society.

One of the closest partners of the Mahalla Institute in the field of employment of youth is the Youth Union. Since the establishment of the Youth Union of Uzbekistan, the issue of ensuring youth employment has been considered a priority task, and as a result of practical activities carried out during the first half of 2017-2019, 184400 youth have been employed. In particular, according to the analysis of activities carried out to ensure keeping up occupied of young people at the cross-section of the years, in 2017, 28760 people, in 2018, 46062 people, in the past 6 months of 2019, 109578 youth were provided with work. This figure indicates that more than 34756 people have been employed during the 6 months of this year compared to the previous two years. With the support of the Youth Union, 673.9 billion sums of soft loans were provided to 4,555 young people through commercial banks and more than 50,000 new jobs were created [10]. The Youth Union of Tashkent city council in cooperation with the mahallas of Tashkent provides an opportunity to attract young people to entrepreneurship and engage them in private business.

In October 2018, the experts of the Republican research center for employment and labor protection under the Ministry of employment and labor relations of the Republic of Uzbekistan conducted a social survey to determine the level of unemployment and poverty in the country. The survey involved 330 self-governing bodies from 66 cities and districts, 3,300 homemakers, and more than 17,000 citizens. According to the results of the survey, the level of unemployment in 
Kashkadarya, Samarkand, and Fergana regions was $9.7 \%$, in Tashkent, the lowest rate was $7.9 \%$, and the number of people wishing to get work was 1 368.6. The unemployment rate among youth (under 30 years) was $15.1 \%$, more than $17 \%$ of those aged $16-25$, among women 12.9\% [11]. According to these statistics, the lowest unemployment rate is in Tashkent. The unemployment rate in 2019 was 9.0 percent compared to the economically active people, this case indicates a decrease of 0.3 percent compared to 2018. However, due to the Covid-2019 pandemic, the unemployment rate in January-June 2020 was $13.2 \%$. According to the state in September 2020, 2 million people are facing the matter of unemployment [12]. Also, there are a group of the people practically unemployed, but not registered in official documents and do not get enough salary for their work, the exact number on this is not known at this time. These data mentioned above show that several problems remain in Tashkent today, including solving the problem of unemployment, particularly unemployed youth.

\section{CONCLUSION}

The current problem of unemployment, which is torturing the countries of the world, is defined as the priority direction of the state policy as an urgent problem in Uzbekistan. In particular, the causes of unemployment in the capital of Uzbekistan - Tashkent can be explained as follows:

First, the majority of young people not having a higher education degree do not have sufficient knowledge and experience in the field of entrepreneurship, including the disbursement and management of allocated loans.
Secondly, the majority of young people do not meet the demand for professions with high demand in the labor market.

Thirdly, the majority of the people in Tashkent are engaged mainly in trade. Vocational retraining of unemployed people is not organized in accordance with the requirements of the labor market.

\section{REFERENCE}

1. https://www.statista.com/statistics/26641 4/unemployed-persons-worldwide/

2. https://www.pv.uz/oz/news/urovenbezrabotitsy-v-uzbekistane-v-2018-godusostavil-93-protsenta

3. http://uza.uz/uz/society/tashkentdaishsizlikin-sabablari-nima-bilanizohlanuvchi 17-09-2018

4. Muallif tomonidan O'zbekiston Respublikasi Statistika qo'mitasi ma'lumotlari asosida tuzilgan. https://stat.uz/uz/223-ofytsyalnaiastatystyka-uz/demografiya-i-truduz/zanyatost-naseleniya-uz/2423-iktisodiyfaol-aholi-bandlar-va-ishsizlar-soni

5. Olmazor tuman hokimligining 2010-2015 yillardagi amaldagi arxivi ma'lumotlaridan

6. "Ko'kcha" MFYning mahalliy arxivi.

7. Ўзбекистон Республикаси Президенти фармони. Ўзбекистон Республикасини янада ривожлантириш бўйича харакатлар стратегияси тўғрисида. Тошкент: «Адолат», 2017. - Б.35

8. Қонун хужжатлари маълумотлари миллий базаси, 28.11.2017 й

9. Fuqarolarning o'zini o'zi boshqarish organlarida mehnat munosabatlarini tartibga solish to'g'risidagi nizom. 2017 yil 27-noyabr, http://lex.uz/docs/3426881

10. O'zbekiston yoshlar ittifoqi tomonidan ikki yarim yil davomida erishilgan natijalar 
to'g'risidagi hisobotdan (2017 yil iyul 2019 yil dekabr).

11. https://www.pv.uz/oz/news/uroven-

bezrabotitsy-v-uzbekistane-v-2018-godusostavil-93-protsenta

12. http://xs.uz/uz/post/2019-jildaozbekistonda-ishsizlik-darazhasi-9-foiznitashkil-qilmoqda 